\title{
Leaf Decomposition in An Intermittent Stream: Channel vs. Riparian Area
}

\author{
Sara Simões *, Ana Lúcia Gonçalves, Inês Rodrigues, Cristina Canhoto, Aingeru Martínez \\ Centre for Functional Ecology, Department of Life Sciences, University of Coimbra, Calçada Martim de \\ Freitas, 3000-456 Coimbra, Portugal \\ Correspondence: sara.cs3@gmail.com; Tel.: +351 239240700
}

\begin{abstract}
Litter decomposition in intermittent streams is driven by the biotic compartment and uniquely shaped by abiotic conditions such as flow variability. In this study, we compared microbial-mediated decomposition of three temperate native leaf species (alder, chestnut and oak) in the channel and riparian area of an intermittent stream. The stream channel presented a total of 8,49 and 35 days of flow, isolated pools and dry conditions, respectively, while the riparian area remained emersed. Independently of the species, decomposition rates after 3 months incubation were higher in the stream channel than in the riparian area. Alder and chestnut's different quality was not translated into distinct fungal biomass, which seems to be related with an earlier fungal colonization and faster decomposition of the former. Leaves incubated in-channel presented higher fungal biomass than in the riparian area. During autumn, even in the absence of water flow, a higher moisture in the stream channel and the presence of isolated pools significantly yielded faster decomposition rates and fungal biomass accrual than in the riparian area. We may expect that, along with the resumption of surface flow, the reestablishment of hydrological connectivity will lead to the lateral and longitudinal transport of dissolved nutrients and organic matter of more (channel) or less (riparia) increased quality, fueling local and downstream communities.
\end{abstract}

Keywords: Flow variability; streambed; riparian; aquatic hyphomycetes; litter quality

\section{Introduction}

Intermittent streams may currently account for more than $50 \%$ of the total length of the global river network [1], and their frequency is projected to significantly increase due to climate change [2]. Even so, their ecological processes and provision of services are still poorly understood [3]. Leaf litter decomposition is a key ecosystem process in forested intermittent watercourses, fueling the in-stream food-webs and contributing to nutrients recycling [4]. This process is driven by the characteristics of the biotic compartment (e.g. litter quality, decomposer and detritivore communities; [5-7]) and uniquely shaped by the abiotic context of the stream, namely its flow variability [8,9], largely responsible for the hydrological connectivity [10] and community structure of the watercourse [11].

In intermittent streams, flow variability creates continuously interchanging lotic, lentic and terrestrial local mosaics [1], influencing litter decomposition rates. Detritus in dry habitats decompose slower than those immersed in water [12-14] due to the imposed limitation of microbial activity [15] and aquatic detritivores density [16]. Flow variability also causes highly variable lateral (e.g. with the riparian area), vertical and longitudinal hydrological connections, resulting in perpetual litter movements among different mosaics. This creates important, but largely unknown, intra- and interseasonal legacy effects for the decomposition process $[17,18]$ and nutrient cycling in these systems.

The main goal of this study was to compare the microbial-mediated decomposition of three temperate leaf species (Alnus glutinosa (L.) Gaertn. - alder [A], Castanea sativa Mill. - chestnut [C], and Quercus robur L. - oak [O]) in the channel and riparian area of an intermittent stream subjected to a high flow variability during autumn. We hypothesized that, independently of the species, leaf litter incubated in the stream channel (vs. riparian area) would exhibit higher decomposition rates and fungal biomass, due to flow/standing water presence. Additionally, the litter quality gradient - alder 
$>$ chestnut $>$ oak - would be translated into similar decomposition rates and fungal biomass patterns among leaf species, independently of the zone.

\section{Results}

Decomposition rates differed between incubation zones (2-way ANOVA, $p=0.004$ ) independently of leaf species $(\mathrm{p}=0.180)$, being 1.7-times higher in the channel than in the riparian area (Figure 1a). Decomposition rates were also dissimilar among litter species $(p<0.001)$ : alder presented 1.9 and 3.2-times higher decomposition rates than chestnut and oak, respectively.

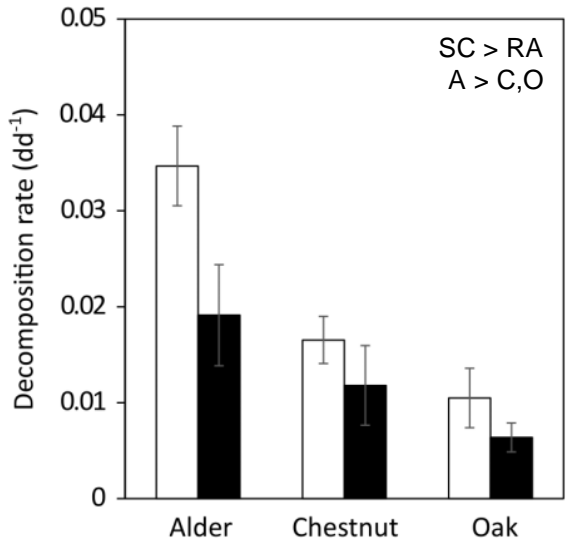

(a)

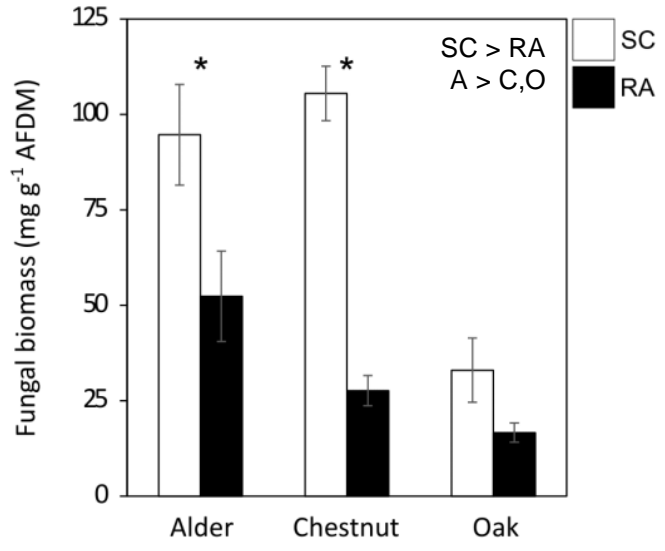

(b)

Figure 1. (a) Decomposition rates in the stream channel (SC) and riparian area (RA) for the three leaf species (Alder A; Chestnut C; Oak O). Statistical differences are also shown among incubation areas and leaf species. $\left(^{*}\right)$ indicates differences between zones within each species (factors interaction).

Fungal biomass was 2.4-times higher in the channel than in the riparian area (2-way ANOVA, $\mathrm{p}$ $<0.001$; Figure $1 b)$ and differed between species $(p<0.001)$, with a significant interaction between both factors $(p=0.004)$. Chestnut and alder presented higher fungal biomass than oak in the stream channel (Figure 1b), while no statistical differences in fungal biomass were found in the riparian area among all the species.

\section{Discussion}

Litter decomposition rates and fungal biomass were consistently higher in the stream channel; differences between zones were mainly determined by the presence of water in the channel along the incubation period, and by the consequent higher remnant moisture during dry periods. Leaf litter quality determined decomposition rates - alder $>$ chestnut $>$ oak - regardless of the zone; however, the importance of the leaf physico-chemical characteristics on fungal biomass was modulated by the zone-specific hydrological conditions.

Our results point to the importance of water presence, even as isolated pools, in maintaining a higher humidity in the channel throughout autumn. These lentic environments, present in the channel for the majority of our study period (opposed to flowing water conditions, present for only 8 days), were likely vital in maintaining a higher microbial-decomposition potential when compared to the terrestrial/riparian environment. This is in agreement with previous works that found faster decomposition rates in patches with higher moisture availability $[14,19]$. Such lower moisture availability in the riparian area, although potentially allowing aquatic hyphomycetes activity [20], might have also determined a microbial community dominated by terrestrial fungi. This, together with a delayed leaching process that defer microbial colonization [21], likely resulted in reduced decomposition rates, $28-44 \%$ inferior in relation to the channel area.

As expected, litter quality effects on decomposition rates seem to prevail independently of the incubation zone. Leaves presenting lower C:N and C:P ratios and leaf toughness, thin cuticles and 
low lignin contents are generally expected to exhibit fast decomposition rates, both in aquatic [22-24] and terrestrial systems [24-26]. The visible, although non-significant, trend in fungal biomass (alder $>$ chestnut $>$ oak) in the riparian area seems to express such intrinsic litter quality differences. On the other hand, the effect of litter quality on fungal biomass in the stream channel was likely strengthened by the favorable hydrological conditions, stimulating leaching and aquatic fungi colonization, particularly of more labile leaves. In fact, an earlier fungal colonization peak may explain the lack of fungal biomass differences between alder and chestnut in the stream channel, after 88 days of incubation.

The higher rates of litter decomposition and fungal biomass content observed in our study in the channel area seem to be related with its higher hydrological heterogeneity. Such conditions likely reduced energetically expensive microbial responses to stress [28] and allowed for an investment of aquatic fungi on growth and degradative activity. Additionally, they may have favoured the development of combined assemblages of aquatic and terrestrial fungi in this area, which may justify the high fungal biomass values registered in relation to other intermittent/drought studies [29,30]. Aquatic hyphomycetes, the main decomposers in freshwaters, are particularly vulnerable to desiccation [31] but respond immediately upon rewetting [32], while the biosynthesis of ergosterol (proxy of fungal biomass) is involved in terrestrial resistance of fungi to air-drying [33]. Whether such microbial biomass accrual and consequent increases in leaf $\mathrm{N}$ content and palatability [34] result in important differences in organic matter quality, locally available for the stream communities in dry or wet conditions, remains to be evaluated.

Our results suggest that lentic habitats such as isolated pools may be crucial for the maintenance of higher moisture levels in the stream channel, before complete flow reestablishment. Such conditions stimulate a leaf species-specific fungal enrichment in the stream channel. Litter conditioning in the dryer riparian area, although slower across all leaf species, may still enhance the food quality potentially available for early-winter recovered aquatic communities. When hydrological connectivity is reestablished, the lateral and longitudinal transport of dissolved nutrients and organic matter, of more (channel) or less (riparia) increased quality, will fuel both local and downstream communities.

\section{Materials and Methods}

\subsection{Study Site}

The study took place in a low-order intermittent stream in Lousã Mountain (central Portugal; $40^{\circ} 03^{\prime} 38.0^{\prime \prime} \mathrm{N} 8^{\circ} 12^{\prime} 26.9^{\prime \prime} \mathrm{W}$ ). The riparian cover was composed mostly of $C$. sativa and Q. robur trees. This area is characterized by a sub-Mediterranean climate, with hot and dry summers with prolonged droughts, and mild and rainy winters [35].

\subsection{Procedures}

Leaves of alder (A. glutinosa), chestnut (C. sativa) and oak (Q. robur), common riparian species in central Portugal, were collected after natural abscission and dried in the dark at room temperature. Ground leaves (IKA Tube-Mill control, Germany) were characterized in molar ratios of nitrogen (N), carbon (C) (IRMS ThermoDelta V advantage with a Flash EA [1112 series]) and phosphorous (P; [36]), as well as total phenolics (\% leaf dry mass [DM]; Folin-Ciocalteau assay, [36]) and toughness, measured with a leaf penetrometer [36]. The three litter species portrayed a litter quality gradient: alder presented the highest quality because of the lowest C:N, C:P, toughness and phenolics contents, and highest $\mathrm{N}: \mathrm{P}$ (Table 1). Chestnut was of intermediate quality and oak was the most recalcitrant species, presenting highest values of C:P and toughness.

Table 1. Initial chemical and structural characteristics of the leaves of alder, chestnut and oak (mean $\pm \mathrm{SE}, \mathrm{n}=3$ ). C:N, C:P and N:P were calculated as molar ratios. For each parameter, different letters indicate significant differences between species (1-way ANOVA followed by Tukey's HSD test; $\mathrm{p}<$ $0.05)$. 


\begin{tabular}{cccc}
\hline & Alder & Chestnut & Oak \\
\hline C:N & $17.8^{\mathrm{a}}$ & $83.7^{\mathrm{c}}$ & $70.9^{\mathrm{b}}$ \\
C:P & $880.1^{\mathrm{a}}$ & $2052.9^{\mathrm{b}}$ & $2183.3^{\mathrm{c}}$ \\
N:P & $49.3^{\mathrm{c}}$ & $24.6^{\mathrm{a}}$ & $30.8^{\mathrm{b}}$ \\
Total phenolics (\% DM) & $1.2^{\mathrm{a}}$ & $3.7^{\mathrm{c}}$ & $2.0^{\mathrm{b}}$ \\
Toughness (g) & $30.5^{\mathrm{a}}$ & $55.6^{\mathrm{b}}$ & $76.5^{\mathrm{c}}$ \\
\hline
\end{tabular}

A total of 12 fine (FM; $10 \times 12 \mathrm{~cm}, 0.5 \mathrm{~mm}$ mesh) mesh bags per species were prepared with $4 \pm$ $0.15 \mathrm{~g}$ leaves. Half of the bags of each species was randomly placed in the stream channel (SC), perpendicularly to the flow direction; the other half was randomly placed in the adjacent riparian area (RA). Litterbags were placed in the field in early Autumn, at which point there was no surface water in the stream channel.

During the 88 days of the study period, hydrological conditions were checked every two days by a remote-controlled photographic camera (GSM Digital Trail Camera HC-300M). Flow was observed for a total duration of 8 days, isolated pools were present for 49 days, and no flow was observed for a duration of 35 days. The riparian area, due to the high slope of the river banks, was never flooded. Temperature was monitored every hour in both zones (Hobo Pendant Datalogger UA001-08; Onset Computer Corp., Cape Cod, MA, U.S.A.).

After the incubation period all litterbags were retrieved, placed in individual zip-lock bags, and transported in a cooler for subsequent determinations. In the laboratory, leaf material from each bag was gently rinsed with distilled water to remove sediments. Then, five random leaf discs were punched out with a cork borer $(10 \mathrm{~mm} \varnothing)$ to determine fungal biomass (see below). The remaining leaf material was oven-dried $\left(60^{\circ} \mathrm{C}, 48 \mathrm{~h}\right)$, weighed, ashed $\left(500^{\circ} \mathrm{C}, 4 \mathrm{~h}\right)$ and reweighed to obtain ashfree dry mass (AFDM).

For fungal biomass determination, punched discs were freeze-dried for $24 \mathrm{~h}$ (lyophilizer CHRIST, ALPHA 1-2 / LD Plus, Osterode am Harz, Germany) and weighed. Ergosterol was extracted by microwave exposure in methanol, separated by pentane [37] and quantified by high performance liquid chromatography (HPLC; Shimadzu Prominence UFLC, Kyoto, Japan) using a HPLC C18 column (Mediterranea sea18, $250 \times 4.6 \mathrm{~mm}, 5 \mu \mathrm{m}$ particle size; Teknokroma). Ergosterol concentration was converted into fungal biomass (5.5 $\mu \mathrm{g}$ ergosterol per mg fungal dry mass; [38]). Results were expressed as mg fungal biomass $\mathrm{g}^{-1}$ AFDM.

\subsection{Data Treatment}

Leaf mass loss was calculated with the following linear model: $b=(\mathrm{M} 0-\mathrm{Mt}) / \mathrm{dd}$, where $\mathrm{b}$ is decomposition linear rate, $\mathrm{M} 0$ is the mean remaining mass in terms of percentage at the initial time, $\mathrm{Mt}$ is the remaining mass in terms of percentage at the end of the incubation period, and dd is the degree-days. Degree-days were used rather than time in order to standardize the rates among zones due to possible temperature differences.

Decomposition rates $\left(\mathrm{dd}^{-1}\right)$ and fungal biomass were analyzed by 2-way ANOVAs (factors: "incubation zone" and "leaf species"). Data were transformed whenever necessary to meet homogeneity assumptions. Post-hoc Tukey's HSD test and planned-comparisons were performed whenever differences were found ( $p<0.05$; Statistica 10 software).

Acknowledgments: Financial support by FCT, within the POCH - Human Capital Operating Program, to SS (Fellowship Reference SFRH/BD/119133/2016), co-funded by the European Social Fund and MCTES national funds, is gratefully acknowledged. This work was also carried out at the R\&D Unit Center for Functional Ecology - Science for People and the Planet (CFE), with reference UIDB/04004/2020, financed by FCT/MCTES through national funds (PIDDAC). The project ReNATURE - Valorization of the Natural Endogenous Resources of the Centro Region (Centro 2020, Centro-01-0145-FEDER-000007) also supported AM (fellowship reference ReNATURE-BPD11A).

Author Contributions: C.C., A.L.G. and A.M. conceived and designed the experiments; A.L.G, I.R. and S.S. performed the experiments; A.M. and S.S. analyzed the data; A.M., C.C and S.S. wrote the paper. 
Conflicts of Interest: The authors declare no conflict of interest. The founding sponsors had no role in the design of the study; in the collection, analyses, or interpretation of data; in the writing of the manuscript, and in the decision to publish the results.

\section{Abbreviations}

The following abbreviations are used in this manuscript:

A: Alder (Alnus glutinosa)

AFDM: Ash-free dry mass

C: Chestnut (Castanea sativa)

DM: Dry mass

O: Oak (Quercus robur)

RA: Riparian area

SC: Stream channel

\section{References}

1. Datry, T.; Larned, S. T.; Tockner, K. Intermittent Rivers: A Challenge for Freshwater Ecology. Bioscience 2014, 64 (3), 229-235. https://doi.org/10.1093/biosci/bit027.

2. Pumo, D.; Caracciolo, D.; Viola, F.; Noto, L. V. Climate Change Effects on the Hydrological Regime of Small Non-Perennial River Basins. Sci. Total Environ. 2016, 542, 76-92. https://doi.org/10.1016/j.scitotenv.2015.10.109.

3. Datry, T.; Boulton, A. J.; Bonada, N.; Fritz, K. M.; Leigh, C.; Sauquet, E.; Tockner, K.; Hugueny, B.; Dahm, C. N. Flow Intermittence and Ecosystem Services in Rivers of the Anthropocene. J. Appl. Ecol. 2018, 55 (1), 353-364. https://doi.org/10.1111/1365-2664.12941.

4. Datry, T.; Foulquier, A.; Corti, R.; von Schiller, D.; Tockner, K.; Mendoza-Lera, C.; Clément, J. C.; Gessner, M. O.; Moleón, M.; Stubbington, R. et al. A Global Analysis of Terrestrial Plant Litter Dynamics in NonPerennial Waterways. Nat. Geosci. 2018, 1-7. https://doi.org/10.1038/s41561-018-0134-4.

5. Bastias, E.; Ribot, M.; Romaní, A. M.; Mora-Gómez, J.; Sabater, F.; López, P.; Martí, E. Responses of Microbially Driven Leaf Litter Decomposition to Stream Nutrients Depend on Litter Quality. Hydrobiologia 2018, 806 (1), 333-346. https://doi.org/10.1007/s10750-017-3372-3.

6. Gonçalves, A. L.; Graça, M. A. S.; Canhoto, C. The Effect of Temperature on Leaf Decomposition and Diversity of Associated Aquatic Hyphomycetes Depends on the Substrate. Fungal Ecol. 2013, 6 (6), 546-553. https://doi.org/10.1016/j.funeco.2013.07.002.

7. Gonçalves, A. L.; Chauvet, E.; Bärlocher, F.; Graça, M. A. S.; Canhoto, C. Top-down and Bottom-up Control of Litter Decomposers in Streams. Freshw. Biol. 2014, 59 (10), 2172-2182. https://doi.org/10.1111/fwb.12420.

8. Migliorini, G. H.; Srivastava, D. S.; Romero, G. Q. Leaf Litter Traits Drive Community Structure and Functioning in a Natural Aquatic Microcosm. Freshw. Biol. 2018, No. January, 341-352. https://doi.org/10.1111/fwb.13072.

9. Acuña, V.; Giorgi, A.; Muñoz, I.; Sabater, F.; Sabater, S. Meteorological and Riparian Influences on Organic Matter Dynamics in a Forested Mediterranean Stream. J. North Am. Benthol. Soc. 2007, 26 (1), 54-69. https://doi.org/10.1899/0887-3593(2007)26[54:MARIOO]2.0.CO;2.

10. Boulton, A. J.; Rolls, R. J.; Jaeger, K. L.; Datry, T. Hydrological Connectivity in Intermittent Rivers and Ephemeral Streams. In Intermittent Rivers and Ephemeral Streams: Ecology and Management; Elsevier Inc., 2017; pp 79-108. https://doi.org/10.1016/B978-0-12-803835-2.00004-8.

11. Larned, S. T.; Datry, T.; Arscott, D. B.; Tockner, K. Emerging Concepts in Temporary-River Ecology. Freshw. Biol. 2010, 55, 717-738. https://doi.org/10.1111/j.1365-2427.2009.02322.x.

12. Corti, R.; Datry, T.; Drummond, L.; Larned, S. T. Natural Variation in Immersion and Emersion Affects Breakdown and Invertebrate Colonization of Leaf Litter in a Temporary River. Aquat. Sci. 2011, 73 (4), 537 550. https://doi.org/10.1007/s00027-011-0216-5.

13. Northington, R. M.; Webster, J. R. Experimental Reductions in Stream Flow Alter Litter Processing and Consumer Subsidies in Headwater Streams. Freshw. Biol. 2017. https://doi.org/10.1111/fwb.12898. 
14. Abril, M.; Muñoz, I.; Menéndez, M. Heterogeneity in Leaf Litter Decomposition in a Temporary Mediterranean Stream during Flow Fragmentation. Sci. Total Environ. 2016, 553, 330-339. https://doi.org/10.1016/j.scitotenv.2016.02.082.

15. Schlief, J.; Mutz, M. Leaf Decay Processes during and after a Supra-Seasonal Hydrological Drought in a Temperate Lowland Stream. Int. Rev. Hydrobiol. 2011, 96 (6), $633-655$. https://doi.org/10.1002/iroh.201111322.

16. Datry, T.; Corti, R.; Claret, C.; Philippe, M. Flow Intermittence Controls Leaf Litter Breakdown in a French Temporary Alluvial River: The “Drying Memory." Aquat. Sci. 2011, 73 (4), 471-483. https://doi.org/10.1007/s00027-011-0193-8.

17. Gliksman, D.; Haenel, S.; Grünzweig, J. M. Biotic and Abiotic Modifications of Leaf Litter during Dry Periods Affect Litter Mass Loss and Nitrogen Loss during Wet Periods. Funct. Ecol. 2017, 32 (3), 1-9. https://doi.org/10.1111/ijlh.12426.

18. Mora-Gómez, J.; Boix, D.; Duarte, S.; Cássio, F.; Pascoal, C.; Elosegi, A.; Romaní, A. M. Legacy of Summer Drought on Autumnal Leaf Litter Processing in a Temporary Mediterranean Stream. Ecosystems 2020, 23 (5), 989-1003. https://doi.org/10.1007/s10021-019-00451-0.

19. Langhans, S. D.; Tiegs, S. D.; Gessner, M. O.; Tockner, K. Leaf-Decomposition Heterogeneity across a Riverine Floodplain Mosaic. Aquat. Sci. 2008, 70 (3), 337-346. https://doi.org/10.1007/s00027-008-8062-9.

20. Chauvet, E.; Cornut, J.; Sridhar, K. R.; Selosse, M. A.; Bärlocher, F. Beyond the Water Column: Aquatic Hyphomycetes Outside Their Preferred Habitat. Fungal Ecol. 2016, 19, 112-127. https://doi.org/10.1016/j.funeco.2015.05.014.

21. Treplin, M.; Zimmer, M. Drowned or Dry: A Cross-Habitat Comparison of Detrital Breakdown Processes. Ecosystems 2012, 15 (3), 477-491. https://doi.org/10.1007/s10021-012-9523-5.

22. Enríquez, S.; Duarte, C. M.; Sand-Jensen, K. Patterns in Decomposition Rates among Photosynthetic Organisms: The Importance of Detritus C:N:P Content. Oecologia 1993, 94 (4), 457-471. https://doi.org/10.1007/BF00566960.

23. Ardón, M.; Pringle, C. M. Do Secondary Compounds Inhibit Microbial- and Insect-Mediated Leaf Breakdown in a Tropical Rainforest Stream, Costa Rica? Oecologia 2008, 155 (2), 311-323. https://doi.org/10.1007/s00442-007-0913-x.

24. Zukswert, J. M.; Prescott, C. E. Relationships among Leaf Functional Traits, Litter Traits, and Mass Loss during Early Phases of Leaf Litter Decomposition in 12 Woody Plant Species. Oecologia 2017, 185 (2), 305 316. https://doi.org/10.1007/s00442-017-3951-z.

25. Loranger, G.; Ponge, J. F.; Imbert, D.; Lavelle, P. Leaf Decomposition in Two Semi-Evergreen Tropical Forests: Influence of Litter Quality. Biol. Fertil. Soils 2002, 35 (4), 247-252. https://doi.org/10.1007/s00374002-0467-3.

26. Four, B.; Cárdenas, R. E.; Dangles, O. Traits or Habitat? Disentangling Predictors of Leaf-Litter Decomposition in Amazonian Soils and Streams. Ecosphere 2019, 10 (4). https://doi.org/10.1002/ecs2.2691.

27. Pesce, S.; Zoghlami, O.; Margoum, C.; Artigas, J.; Chaumot, A.; Foulquier, A. Combined Effects of Drought and the Fungicide Tebuconazole on Aquatic Leaf Litter Decomposition. Aquat. Toxicol. 2016, 173, $120-131$. https://doi.org/10.1016/j.aquatox.2016.01.012.

28. Schimel, J.; Balser, T. C.; Wallenstein, M. Microbial Stress-Response Physiology and Its Implications for Ecosystem Function. Ecology 2007, 88 (6), 1386-1394. https://doi.org/10.1890/06-0219.

29. Monroy, S.; Menéndez, M.; Basaguren, A.; Pérez, J.; Elosegi, A.; Pozo, J. Drought and Detritivores Determine Leaf Litter Decomposition in Calcareous Streams of the Ebro Catchment (Spain). Sci. Total Environ. 2016, 573, 1450-1459. https://doi.org/10.1016/j.scitotenv.2016.07.209.

30. Dieter, D.; Frindte, K.; Krüger, A.; Wurzbacher, C. Preconditioning of Leaves by Solar Radiation and Anoxia Affects Microbial Colonisation and Rate of Leaf Mass Loss in an Intermittent Stream. Freshw. Biol. 2013, 58 (9), 1918-1931. https://doi.org/10.1111/fwb.12180.

31. Bärlocher, F. Reproduction and Dispersal in Aquatic Hyphomycetes. Mycoscience 2009, 50 (1), 3-8. https://doi.org/10.1007/s10267-008-0449-x.

32. Fierer, N.; Schimel, J. P.; Holden, P. A. Influence of Drying-Rewetting Frequency on Soil Bacterial Community Structure. Microb. Ecol. 2003, 45 (1), 63-71. https://doi.org/10.1007/s00248-002-1007-2.

33. Dupont, S.; Lemetais, G.; Ferreira, T.; Cayot, P.; Gervais, P.; Beney, L. Ergostol Biosynthesis: A Fungal Pathway for Life on Land. Evolution (N. Y). 2012, 66 (9), 2961-2968. https://doi.org/10.5061/dryad.pd28pm7n. 
34. Bärlocher, F.; Sridhar, K. R. Association of Animals and Fungi in Leaf Decomposition. In Freshwater Fungi; 2014. https://doi.org/10.1515/9783110333480.413.

35. European Environmental Agency. Europe's Biodiversity - Biogeographical Regions and Sea. The Mediterranean Biogeographical Region; 2002.

36. Graça, M. A. S.; Bärlocher, F.; Gessner, M. O. Methods to Study Litter Decomposition: A Practical Guide; Graça, M. A. S., Bärlocher, F., Gessner, M. O., Eds.; Springer: The Netherlands, 2005; Vol. 51. https://doi.org/10.1111/j.1365-2427.2005.01501.x.

37. Canhoto, C.; Calapez, R.; Gonçalves, A. L.; Moreira-Santos, M. Effects of Eucalyptus Leachates and Oxygen on Leaf-Litter Processing by Fungi and Stream Invertebrates. Freshw. Sci. 2013, 32 (2), 411-424. https://doi.org/10.1899/12-062.1.

38. Gessner, M. O.; Chauvet, E. Ergosterol-to-Biomass Conversion Factors for Aquatic Hyphomycetes. Appl. Environ. Microbiol. 1993, 59 (2), 502-507.

(C) 2020 by the authors; licensee MDPI, Basel, Switzerland. This article is an open access article distributed under the terms and conditions of the Creative Commons by Attribution (CC-BY) license (http://creativecommons.org/licenses/by/4.0/). 